DOI: https://doi.org/10.31933/dijdbm.v2i6

Received: $15^{\text {th }}$ September 2021, Revised: $20^{\text {th }}$ October 2021, Publish: $30^{\text {th }}$ November 2021

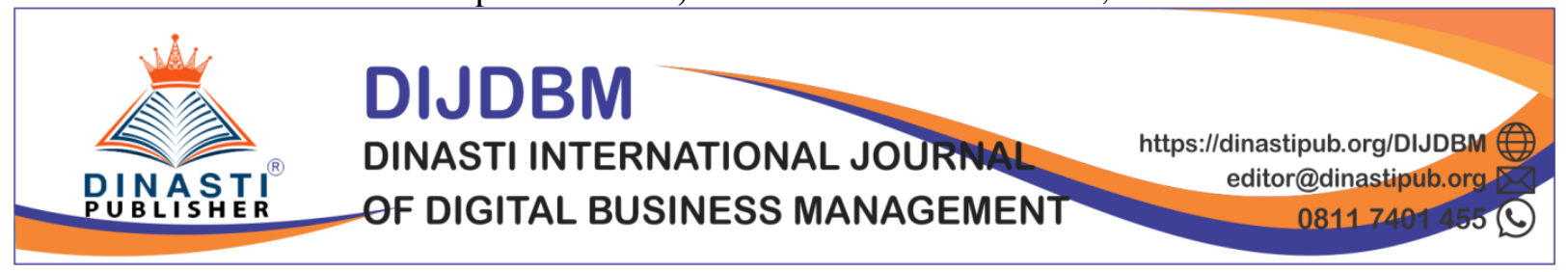

\title{
AN ANALYSIS OF THE PERFORMANCE OF THE AVIATION INDUSTRY IN INDONESIA: IN PANDEMIC PERIOD WITH SERVQUAL METHOD AND IMPORTANCE PERFORMANCE ANALYSIS
}

\author{
Endri Sentosa $^{1}$, Maya Syafriana Effendi ${ }^{2}$, Shinta Rahma Diana ${ }^{3}$ \\ ${ }^{1}$ Faculty of Economics and Business UPI YAI, esanuansa63@gmail.com \\ ${ }^{2}$ Faculty of Economics and Business UPI YAI \\ ${ }^{3}$ National Research and Innovation Agency (BRIN), Indonesia, shinta.rahmadiana@gmail.com
}

\section{Corresponding Author: Endri Sentosa}

Abstract: The aviation industry is one of the most globally affected industries by the COVID19 pandemic. It employs millions of people and supports tens of millions of others, as well as being the nerve center of international business and tourism. The losses of aviation industry will extend to its branches industries. The determination of policies that are not in favor of the industry related to the Avtur VAT, disharmony between ministries has caused the impact of this covid-19 adding heavy burden in industry sector. High operational costs, aircraft leasing, maintenance and others will be higher if the exchange rate also increases. This study aims to determine the analysis of the performance of national aviation industry due to the Covid19 pandemic. The results of this study are expected to be used as input in formulating policies in order to increase economic value in the aviation industry. Method of research which was done, namely comparing literature reviews from journals that discussed airlines with the use of Servqual theory and applied the Importance Performance Analysis method, and the authors made the descriptive analysis. The results of the study showed that covid 19 had a significant impact on the aviation industry, and the results of the performance analysis suggested that in order to survive in Covid-19 condition, the government needed to involve to provide a stimulus to the aviation industry.

Keywords: industry, aviation, covid 19, cost, policy

\section{INTRODUCTION}

The history of airline industry or the aviation industry in Indonesia, starting in early 1949, it was a milestone for commercial aviation. This government-owned airline was originally named Indonesian Airways, flying from Jogjakarta to Jakarta with a plane called "Seulawah" which 
means mountain of gold. This airline is recorded in the history of the struggle of the Indonesian people, because it had important role in fighting against Dutch aggression (Garuda Indonesia, 2009). Then this airline changed its name to Garuda Indonesia.

Significant development of Garuda Indonesia to get to its current position have a long journey. In its early period, it had 27 aircraft with only 1 international route and until now it has almost 200 aircraft with 36 international routes (Mujiono, D. I. K. (2018). The progress of aviation in Indonesia is of course not only for Garuda Indonesia, but also as pioneer in the growth of the aviation industry in Indonesia. The development of national aviation industry has experienced up and down in line with national and global economic growth. From the data of OAG Aviation Worldwide which released by Databoks, positive growth at the end of 2019, the global aviation industry experienced a slowdown as it entered 2020 and began to reach negative growth after 27 January 2020, and continued to fall freely until 23 March 2020, with negative growth reaching -30 (Databoks, 2020).

There are 12 airlines that serve passengers' domestic flights listed on the official website of Ministry of Transportation, namely PT. Garuda Indonesia, PT. Indonesia AirAsia, PT. Lion Mentari Airlines, PT. Wing Abadi Airlines, PT. Sriwijaya Air, PT. Travel Express Aviation, PT. Citilink Indonesia, PT. Transnusa Aviation Mandiri, PT. Batik Air Indonesia, PT. NAM Air, PT. ASI Pudjiastuti Aviation, and PT. Aviastar Mandiri. From the available data, although the number of domestic airlines are so quite many, domestic flight services are dominated by 2 main groups, the first is the Garuda Indonesia Group which has $46 \%$ of the domestic flight market and serves 738 domestic flights per day. This group consists of Garuda Indonesia, Citilink, Sriwijaya Air, and NAM Air. Second, Lion Group which holds $50 \%$ of the domestic flight market and serves 779 domestic flights per day. This group consists of Lion Air, Batik Air, and Wings Air. Meanwhile, other airlines only serve special routes with relatively small aircraft. Only Indonesia AirAsia participates in serving major routes such as those carried out by Garuda Indonesia Group and Lion Group, which are 46 domestic flights per day (Permana, 2019).

The spread of corona virus pandemic has an impact on the world economy. The threat of a recession has appeared and some business sectors are at critical point. Aviation business is the business sector that becomes th most affected first and hardest. The corona pandemic has caused the global aviation industry to lose passengers amount $\mathrm{Rp} 469$ trillion this year. The domestic aviation industry experienced a very extreme contraction, as a result the country lost more than 18 billion US dollars in foreign exchange due to this pandemic.

Airlines are currently at a disadvantage position in a business perspective, this is illustrated by the background above.The expected sales from passengers are getting further from the expected profit value. The decline in the number of passengers reached 24 million people (January-April 2019), it decreased $20.5 \%$ compared to the same period last year. "The largest 
percentage of decline in the number of airplane passengers occurred at Kualanamu Airport, Medan, which reached 32.5 percent. Then, followed by Juanda International Airport, Surabaya at 25.2 percent, Hasanuddin International Airport, Makassar at 24.8 percent, Soekarno-Hatta International Airport at 21.9 percent and Ngurah Rai International Airport, Bali at 13 percent" (Sukmana, 2019).

Cost of goods sold (COGS) which is the main element of production cost cannot be suppressed, because it is related to market price. The position of government becomes dilemma, to implement a low-cost flight policy, entering the new normal era, because the aviation industry has already endured a high burden since the national PSBB was implemented. Meanwhile, in terms of consumer behavior, airlines are expected to be able to provide maximum service (serviqual) with all the burdens that have undermined the airline.

Based on some condition above, a comprehensive internal and external policy are needed to maintain market share and business continuity. One of the efforts which made to formulate the policy, first, conducting a study on how the performance of aviation industry in Indonesia during the Covid-19 pandemic is needed.

\section{The Aim of Research}

Based on the background which written above, the objectives of this study are to:

a. Know the impact of Covid-19 pandemic on the aviation industry in Indonesia.

b. Analyze the performance of aviation industry in Indonesia during the pandemic using Servqual theory and the Importance Performance Analysis method.

\section{RESEARCH METHOD}

This paper use qualitative technique to accomplish the purpose of this research that are descriptive studies. Qualitative method allows the researcher to explore and better understand the complexity of a phenomenon (Mohajan, 2018). Descriptive method is a method that describes what currently prevails in which there is an attempt to describe, record, analyze and interpret the current conditions (Suryana et al. 2013). Method of research which was conducted here was comparing literature reviews from journals, articles and other secondary data that discussed the performance of airlines using descriptive analysis of discussion. Servqual theory and the Importance Performance Analysis (IPA) method were used in discussion. Both of these methods were used to see how the aviation industry performs during the pandemic. Servqual Scale analysis proposed by Parasuraman, Zeithaml, and Berry (1988) identifies five dimensions of service quality measurement, namely reliability, responsiveness, assurance (guarantee), tangibles (direct evidence), and empathy. Importance Performance Analysis (IPA) matrix with elements of aviation fuel prices, aircraft leasing, and maintenance costs.

\section{SERVQUAL Concept}


In the beginning, Parasuraman et al (1985) identified ten main dimensions with 22 variables related to services and then analyzed using factor analysis. These criteria include 10 potential dimensions which completed each other, namely tangibles, reliability, responsiveness, communication, credibility, security, competence, courtesy, understanding and access. Then, in the next research, Parasuraman et al in 1988 perfected these dimensions, then processed again so that finally they were simplified into 5 dimensions, namely:

1) Tangibles; includes physical facilities, equipment, employees, and means of communication

2) Reliability; namely the ability to provide the promised service promptly, accurately, and satisfactorily

3) Responsiveness; namely the desire of the staff to help customers and provide responsive service

4) Guarantee (assurance); includes the knowledge, ability, politeness and trustworthiness of staff, free from danger, risk or doubt

5) Empathy; includes ease of doing relationships, good communication, personal attention, and understanding the needs of customers

\section{FINDINGS AND DISCUSSION}

\section{The Importance Performance Analysis (IPA)}

According to Tjiptono, et. al (2011) this technique was first proposed by Martilla and James in 1977. In this technique, respondents are asked to assess the level of importance and performance of the company, then the average value of the level of importance and performance is analyzed in the Importance Performance Matrix, which The $\mathrm{X}$ axis represents perception while the $\mathrm{Y}$ axis represents expectations, then the results will be obtained in the form of four quadrants, with the interpretation of the quadrants as follows:

1) Top Priority (Concentrate Here)

In this quadrant, there are factors which considered important and are expected by customers but the performance of company is considered unsatisfactory so that the company needs to concentrate on allocating resources to improve performance that fall into this quadrant.

2) Maintain Achievement (Keep Up the Good Work)

In this quadrant, there are factors which are considered important and are expected to be supporting factors for customer satisfaction so that companies are obliged to maintain the achievements of this performance.

3) Low Priority

In this quadrant, there are factors which considered to have a low level of perception or actual performance and they are not too important and or not too be expected by consumers so that companies do not need to prioritize or pay more attention to these factors.

4) Overkill (Possibly Overkill) 
In this quadrant, there are factors which considered not too important and not too be expected by customers so that the company is better to allocate resources related to these factors to other factors that have a higher priority level.

\section{THE IMPACT OF COVID 19 ON THE AVIATION INDUSTRY}

The Covid-19 pandemic has broken the global and national aviation industry at least. Starting in January 2020, the growth of global flight schedules experienced a sharp correction. Slowly and surely starting on January 20, 2020, it was in a negative position, and decreased sharply to minus $10 \%$ after February 10, 2020. It becomes empirical evidence that this industry has been in a disadvantageous position.

Almost all countries experiences turbulence, decreasing and breaking other businesses related to the aviation industry. The figure 2.1 below shows pre-pandemic capacity, during the pandemic and latest trends.

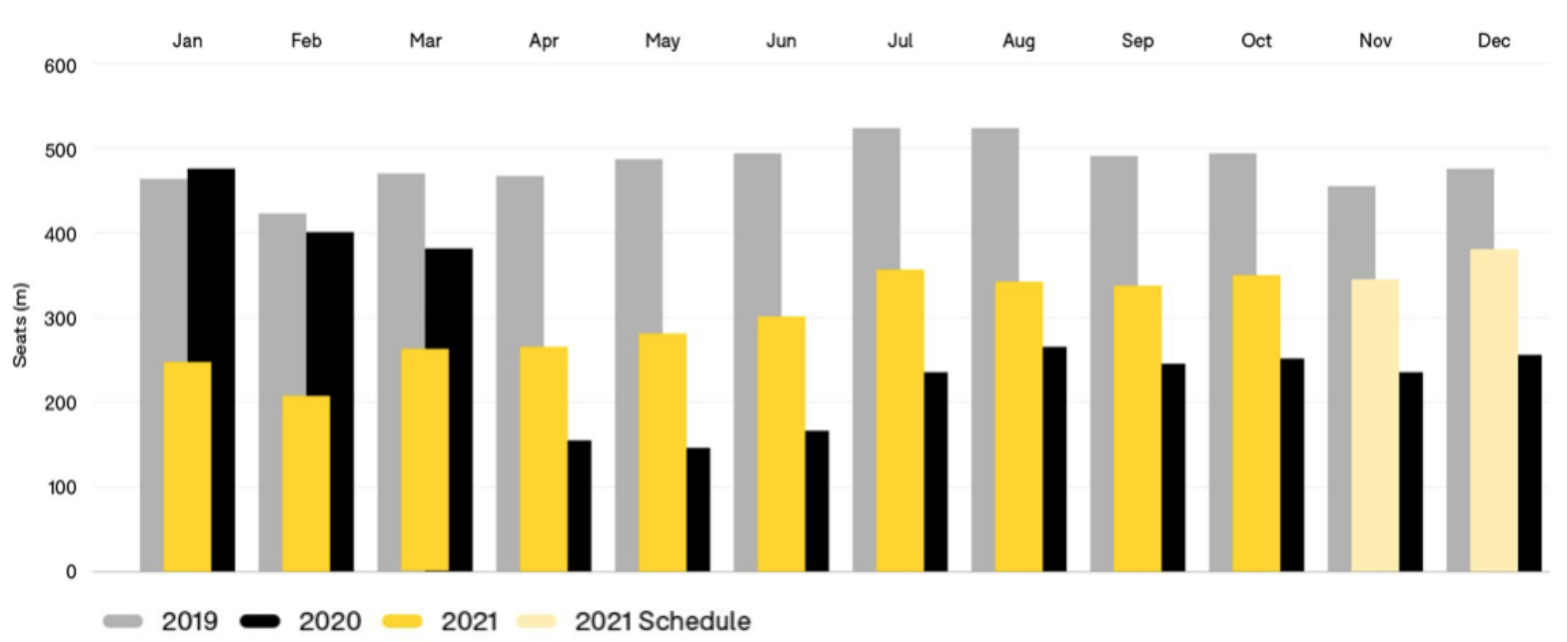

Figure 2.1 Global Scheduled Seat Capacity Year-Over-Year Source: OAG Aviation Worldwide, 2021

The global impact of covid on aviation and several other sectors are (i) air passenger traffic: An overall reduction of air passengers (both international and domestic) ranging from $60 \%$ in 2020 compared to 2019 (by ICAO); (ii) Airports: An estimated loss of approximately 64.6\% of passenger traffic and $66.3 \%$ or over USD 125 billion airport revenues in 2020 compared to business as usual (by ACI); (iii) Airlines: A 65.9\% decline of revenue passenger kilometres (RPKs, both international and domestic) in 2020 compared to 2019 (by IATA); (iv) Tourism: A decline in international tourism receipts of USD 1.3 trillion in 2020, compared to the USD 1.5 trillion generated in 2019 (by UNWTO); (v) Trade: A fall of global merchandise trade volume by $5.3 \%$ in 2020 compared to 2019 (by WTO); (vi) Global economy: An estimated -3.2\% to $3.5 \%$ contraction in world GDP in 2020, far worse than during the 2008-09 financial crisis (by IMF and World Bank) (Hasegawa, 2021). 
The following is a graph showing the significant revenue loss in Africa, Asia/Pacific, Europe, Latin America, Middle East, North America in 2020. The largest revenue loss in Asia/Pacific was -120 (USD billion). Meanwhile, other data states that the Asia Pacific region is the region which most severely affected by Covid-19. It is because the source of transmission of this virus is in China, which in fact is the center of high population mobility. The figure 2.2 below shows compilation of economic, social, regional and statistical impacts.

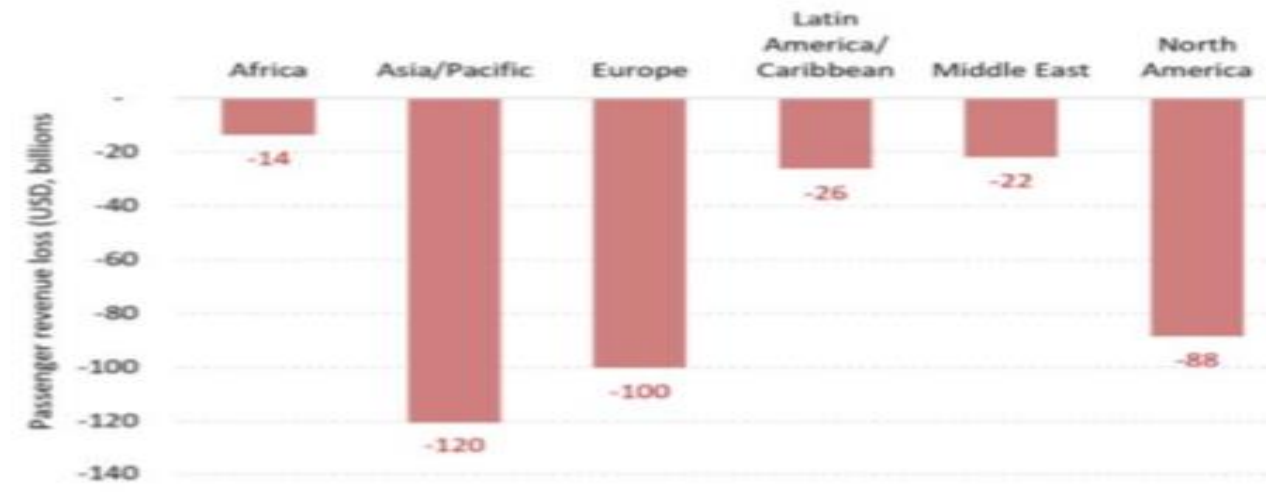

Figure 2.2 Airline Passenger Revenue Losses by Region Source: Hasegawa, 2021

The whole aviation industry was affected. According to IATA, passenger air transport measured as revenue passenger kilometre was down 90\% year-on-year in April 2020 and still down $75 \%$ in August. It has put the liquidity buffers of airline companies under pressure even if a significant share of its costs are variable (around 50\%, notably fuel accounting for $25 \%$ of the total costs) and the recent drop in oil prices has decreased airlines operating costs (OECD, 2020).

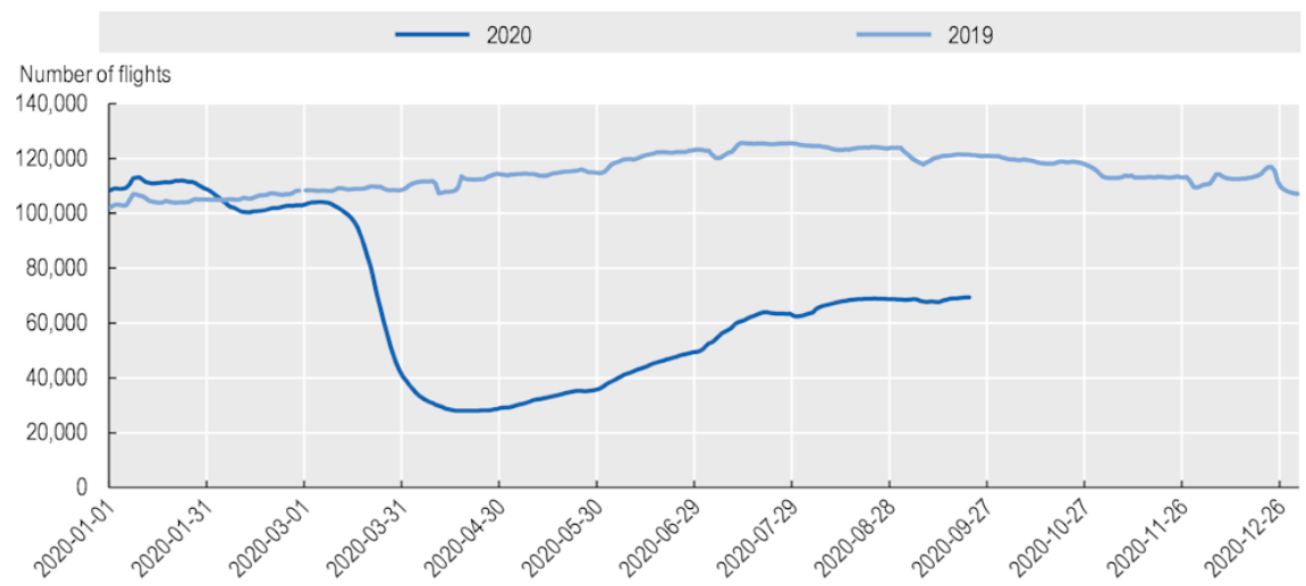

Figure 2.3 Commercial Air Traffic, World

Number Of Flights Tracked Daily by Flight Radar 24, 2020 v. 2019

Source: OECD, 2020 
The conditions above are an illustration of the impact of Covid on the global aviation industry. The condition of the aviation industry in Indonesia is also experiencing difficult times due to COVID 19. According to the Central Statistics Agency (BPS) recorded that passengers of air (BPS) recorded that passengers of air transportation were as many as 16.7 million people during January-March 2020, it decreased 10.12 percent compared to the same period in 2019. Meanwhile, international passengers fell 24.15 percent to 3.4 million people compared to the first three months of 2019 "During January-March 2020, the number of domestic passengers was 16.7 million and international passengers were 3.4 million," said Kecuk, as he is known, Monday 4/5/2020. Meanwhile, during the Covid-19 pandemic, air passengers throughout March 2020 were only 4.6 million people, a decrease of 20.84 percent compared to February 2020. The number of passengers for overseas (international) destinations fell deeper to the level of 50.44 percent to 558, 7 thousand people." (Tribunnew.com, 2020). Whereas previously, Indonesia's foreign exchange income contributed by the tourism sector had a positive trend from 2009 to 2019 , as shown in the following figure 2.4:

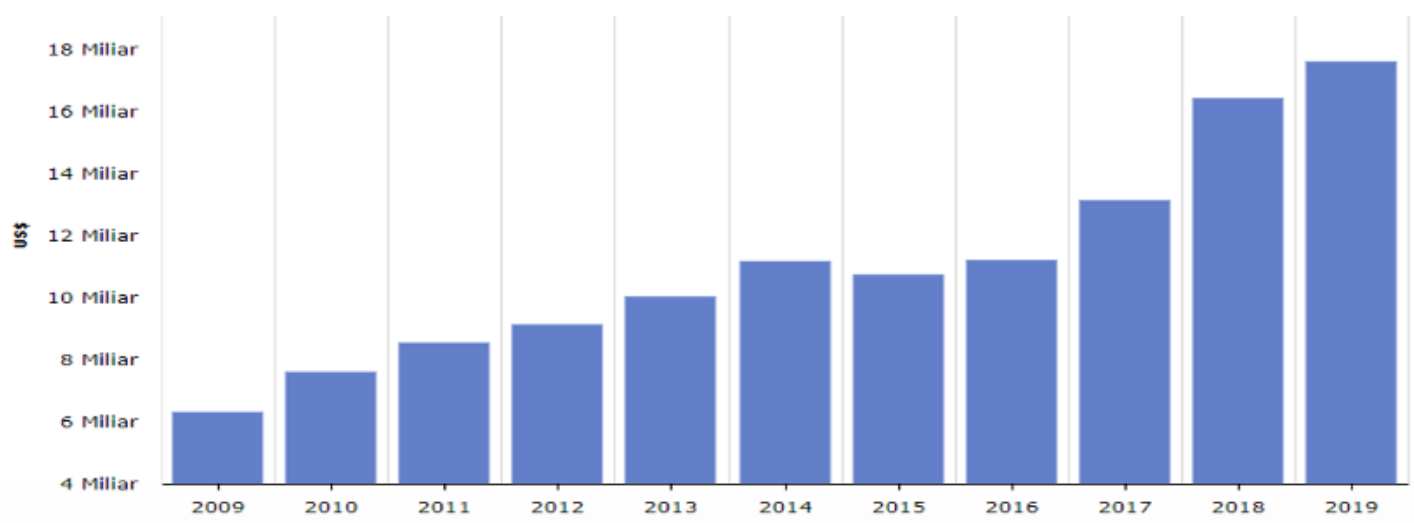

Figure 2.4 Indonesian Foreign Exchange Income from the Tourism Sector (2009 - 2019E) Source: Databoks, 2018

This data provides evidence that the airline industry has entered a transition period and needs to take concrete actions to save itself from the wave of recession and business collapse. The decline in the number of passengers during the pandemic is a test for the aviation business to survive or close and hopes for a rescue policy from government. The state must also be aware that with the fall of aviation industry, foreign exchange were expected to be obtained from this industry and industries related to aviation, it lost billions of dollars.

\section{AN ANALYSIS OF AVIATION INDUSTRY PERFORMANCE}

To save the national aviation industry as a result of the pandemic (covid 19), it is necessary to review the policies that help the aviation business world. The downturn due to the pandemic and high operating cost structure should be the concern of stakeholder in this industry. Internal improvements with marketing concept approach can be done with strong support from external 
factors of this industry, such as avtur subsidy policy, ceiling price and floor price policies in determining ticket prices, as well as exchange rate fluctuation. Successful services marketing strategy also involves integrating a focus on the customer throughout the firm and across all functions. All company functions - marketing, selling, human resources, operations, and R\&D - must work together to create effective services marketing strategy (Zeithaml, et. al (2010). The servqual approach and the IPA (Importance Performance Analysis) matrix are only an alternative but it is very important to maintain a business rhythm so that it is profitable and always prioritizes customer satisfaction. The following table shows the servqual (figure 3.1 and 3.2) and IPA (figure 3.3) approaches to find possible solutions to save the national aviation industry.

\section{SERVQUAL Analysis}

Table 3.1 Servqual Analysis

\begin{tabular}{|c|c|c|c|}
\hline No & Variable & Attribute & Statement \\
\hline 1 & Tangiable & $\begin{array}{l}\text { - } \text { The equipment used meets current } \\
\text { standard. } \\
\text { - } \text { Visual facilities. }\end{array}$ & $\begin{array}{l}\text { - This standard has been } \\
\text { fulfilled. }\end{array}$ \\
\hline 2 & Reliability & $\begin{array}{l}\text { - Provide services as promised. } \\
\text { - Reliable in handling flight problems } \\
\text { for passengers. } \\
\text { - Delivering flight service information } \\
\text { correctly. } \\
\text { - Delivering flight schedules correctly } \\
\text { based on the schedule set. } \\
\text { - Keep records/documents without } \\
\text { error. }\end{array}$ & $\begin{array}{l}\text { - Everything that is } \\
\text { displayed in the attributes } \\
\text { must be fulfilled by the } \\
\text { aviation industry. } \\
\text {-Some mistakes which often } \\
\text { made are about schedule } \\
\text { information for some } \\
\text { airlines especially those } \\
\text { that are always delayed. }\end{array}$ \\
\hline 3 & Responsiveness & $\begin{array}{l}\text { - Inform the candidate of passengers } \\
\text { about the certainty of flight time. } \\
\text { - Immediate/fast service for } \\
\text { candidate of passengers. } \\
\text { - Willingness to help the candidate } \\
\text { of Airline Passengers. } \\
\text { - Readiness to give respond to } \\
\text { passenger requests. }\end{array}$ & $\begin{array}{l}\text { - Airlines must be sensitive } \\
\text { to the need of candidate of } \\
\text { passengers. } \\
\text { - Mistakes which often } \\
\text { made are about schedule } \\
\text { information, especially for } \\
\text { some airlines that are } \\
\text { always delayed. }\end{array}$ \\
\hline 4 & Assurance & $\begin{array}{l}\text { - The attitude of the officers that built } \\
\text { trust of the candidate oc passengers. } \\
\text { - Make the candidate of passengers } \\
\text { feel safe when making transactions? } \\
\text { - Employees who are consistently } \\
\text { polite. }\end{array}$ & $\begin{array}{l}\text { - Other mistakes which } \\
\text { often made is about crisis } \\
\text { handling, especially for } \\
\text { some airlines that always } \\
\text { make passengers feel } \\
\text { disappointed. }\end{array}$ \\
\hline
\end{tabular}




\begin{tabular}{|c|c|c|c|}
\hline No & Variable & Attribute & Statement \\
\hline & & $\begin{array}{l}\text { Employees who are able to answer } \\
\text { questions from customers/candidate } \\
\text { of passengers. }\end{array}$ & \\
\hline 5 & Empathy & $\begin{array}{l}\text { - Officers give individual attention to } \\
\text { the candidates of passengers. } \\
\text { - Officers who treat the candidate of } \\
\text { passengers with care. } \\
\text { - Really put the interests of candidates } \\
\text { of passengers. } \\
\text { - Officers understand the needs of } \\
\text { candidate of passengers. }\end{array}$ & $\begin{array}{l}\text { - This has become part of } \\
\text { the airline business, giving } \\
\text { full service to passengers. } \\
\text { This needs further } \\
\text { attention. }\end{array}$ \\
\hline
\end{tabular}

Source: Processed Data

\section{Identify External Factors}

Table 3.2 Identify External Factors

\begin{tabular}{|l|l|l|l|}
\hline No & \multicolumn{1}{|c|}{ Variable } & \multicolumn{1}{|c|}{ Attribute } & \multicolumn{1}{c|}{ Statement } \\
\hline 1 & AVTUR Price & $\begin{array}{l}\text { Give influence on HPP. } \\
\text { - Can undermine the long-term cost } \\
\text { structure. }\end{array}$ & $\begin{array}{l}\text { The support of government is } \\
\text { needed for this fuel price. }\end{array}$ \\
\hline 2 & $\begin{array}{l}\text { Exchange Rate } \\
\text { Fluctuation }\end{array}$ & $\begin{array}{l}\text { This is a law market, which can be } \\
\text { difficult to be controled and needed } \\
\text { periodic adjustments. }\end{array}$ & $\begin{array}{l}\text { Exchange rate management is } \\
\text { needed, related to contracts and } \\
\text { aircraft rent, if it is possible } \\
\text { then a hedging policy is } \\
\text { needed. }\end{array}$ \\
\hline 3 & $\begin{array}{l}\text { Lowest ticket } \\
\text { price policy }\end{array}$ & $\begin{array}{l}\text { It relates with proper ticket price } \\
\text { for a type of flight route. }\end{array}$ & $\begin{array}{l}\text { Need a comprehensive } \\
\text { discussion with government to } \\
\text { find a reasonable price. }\end{array}$ \\
\hline
\end{tabular}

Source: Processed Data

For the airlines and aviation industry players, the Servqual approach is an internal improvement that should run and needs to be improved. Competition in aviation services has reached a high level to be able to answer the needs of candidate passengers or customers.The results of mapping analysis using the Servqual approach show that the internal factors which are represented by five variablescan still be said to be good overall. Things that need attention are the delay in the Reability and Responsiveness variables, as well as the crisis handling in the Assurance variable. Related to these variables, anticipatory steps can still be taken, although uneasy efforts are needed too. 


\section{AN ANALYSIS OF IMPORTANCE PERFORMANCE ANALYSIS (IPA)}

The following IPA analysis, the author compared 4 quadrants which display the positioning of national airlines. This section discusses the mapping of performance values (X) and expectations (Y), from these results a matrix consisting of four quadrants will be formed, each quadrant describing the priority scale in making policies, either in the form of improving performance or maintaining company performance. The following figure 3.3 is the distribution of performance data and customer expectations:

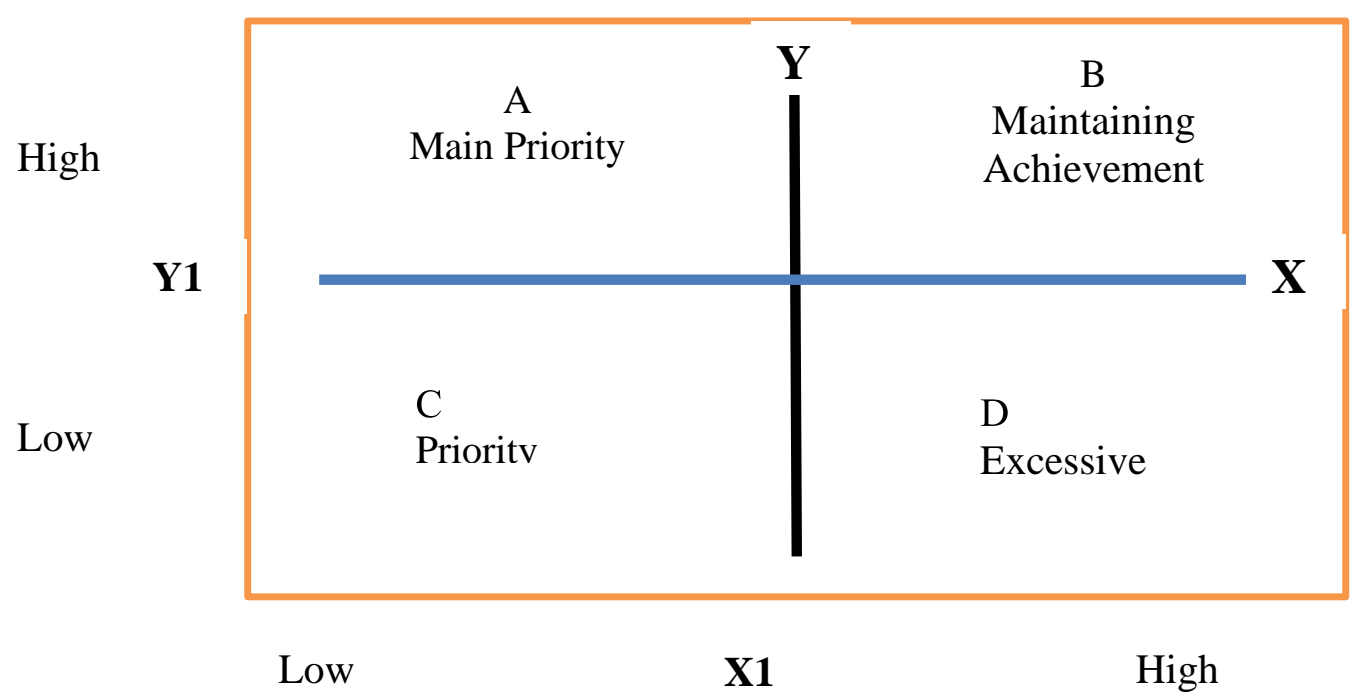

Figure 3.3 Importance Performance Analysis (IPA)

Source: Adapted from Martilla \& James, 1977

The quadrants that were be described further, namely quadrants A and B because these quadrants were types of quadrants which considered important by Customer, so that they became priority that the company needed to pay attention to, because quadrant A needed to be improved by Company and quadrant B must be maintained by the Company. From this figure, the condition of aviation industry can be interpreted as follows:

\section{Quadrant A}

Quadrant A showed factors or attributes which considered important by customers but they were not implemented properly by the company. There are several indicators related to this quadrant:

a. The services provided by airlines were good, although there were airlines that do not satisfy their customers.

b. The range of ticket prices which had been set by airlines was still high in the eyes of consumers.

c. Discounts which given by airlines were good. 
d. The ticket prices offered by airlines were not in accordance with the quality of service

e. Some of the price packages offered are affordable/attractive

Thus, these items became the main priority scale of company for improvement.

\section{Quadrant B}

Quadrant B shows the factors or attributes which considered important and satisfy customers and they had been implemented well by the industry. The variables included in this quadrant were as follows:

a. Airlines have a good response when there is a customer request regarding the need for flight services

b. The airline service transaction system run well

c. Employees who work in airlines industry prioritize the interests of customers

d. The airline employees' performance are neat and professional

e. The services of each airline spread throughout Indonesia

Thus, the performance of these items needed to be maintained by the airline.

\section{Quadrant C}

Quadrant C shows some factors which considered less important by customers and they were not implemented properly by the company.

\section{Quadrant D}

Quadrant D shows factors or attributes which considered less important by the company but they were carried out excessively by the company.

From these 4 quadrants which need to be considered by airlines were quadrants $\mathrm{A}$ and $\mathrm{B}$, which related with services, prices and main issues in airlines. At least to survive in the Covid19 condition, the government needs to involve to provide a stimulus to the aviation industry.

\section{CONCLUSION}

The impact of covid 19 on the aviation industry has entered a transition period and it is necessary to take concrete actions to save ourselves from the wave of recession and business collapse. Continuing from the results of study, a performance analysis was carried out, which based on the results of the initial study through the Servqual and IPA approaches, indicating that airlines need to rearrange internal constraints, especially the problem in determining the Cost of Goods Sold (HPP) due to the appearance of external factors outside of internal cost functions, such as Avtur fuel prices, exchange rate fluctuation and government policies in terms of lowest ticket prices. The government as a regulator in the transportation sector needs to take a comprehensive approach, considering that the aviation industry is very dominant in boosting other sectors, in creating the trickledown effect and economic agglomeration. 


\section{ACKNOWLEDGEMENTS}

Authors are very grateful to Indonesia National Institute of Aeronautics and Space (LAPAN) and LPT YAI for good cooperation. We hope that the suggestions and discussion in this paper can be used by the relevant parties, especially the aviation industry.

\section{BIBLIOGRAPHY}

A. Parasuraman, Valarie A. Zeithaml, and Leonard L. Berry. (1988). "SERVQUAL: A MultipleItem Scale for Measuring Consumer Perceptions of Service Quality”. Journal of Retailing. Vol 64 (1) pp 12- 37.

A. Parasuraman, Valarie A. Zeithaml, and Leonard L. Berry. (1985). "A conceptual model of service quality and its implications for future research" Journal of marketing. Vol. 49. DOI: $10.2307 / 1251430$. https://www.researchgate.net/publication/225083670_A_Conceptual_Model_of_Service_Qu ality_and_its_Implication_for_Future_Research_SERVQUAL

Databoks. (2018). What is the Foreign Exchange Income from the Indonesian Tourism Sector?. https://databoks-katadata-coid.translate.goog/datapublish/2018/09/10/berapa-pendapatan-devisa-dari-sektorpariwisata-indonesia? $\mathrm{x}$ tr_sl=id\& $\mathrm{x}$ tr tr tl=en\& $\mathrm{x}$ tr $\mathrm{hl}=\mathrm{en} \& \mathrm{x}$ tr_pto=nui,sc Databoks. (2020). Penerbangan Global Anjlok Sepanjang 2020 Terimbas Covid-19, from Databoks: https://databoks.katadata.co.id/datapublish/2021/02/11/penerbangan-globalanjlok-sepanjang-2020-terimbas-covid-19

Garuda Indonesia. (2009). Annual Report Garuda Indonesia 2009. https://www.garudaindonesia.com/content/dam/garuda//files/pdf/investor-relations/report/2009.pdf

Hasegawa, Toru. (2021). ICAO. Effects of Novel Coronavirus (COVID-19) on Civil Aviation: Economic Impact Analysis, Economic Development - Air Transport Bureau, Montreal, Canada. https://www.icao.int/sustainability/Documents/Covid19/ICAO_coronavirus_Econ_Impact.pdf

Martilla, J. and James, J. (1977). Importance-Performance Analysis. Journal of Marketing. 41(1), 77-79.

Mohajan, Haradhan. (2018). Qualitative Research Methodology in Social Sciences and Related Subjects. Journal of Economic Development, Environment and People. Vol-7, Issue 01, 2018, pp. 23-48.

Mujiono, D. I. K. (2018). Tantangan Industri Penerbangan Indonesia Menuju ASEAN Open Sky Policy. Jurnal Hubungan Internasional Interdependence, 3(1).

OAG Aviation Worldwide. (2021). How And When Will Aviation Recover From Covid-19?. https://www.oag.com/coronavirus-airline-schedules-data

OECD. (2020). COVID-19 and the aviation industry: Impact and policy responses. OECD Policy Responses to Coronavirus (COVID-19). https://www.oecd.org/coronavirus/policyresponses/covid-19-and-the-aviation-industry-impact-and-policy-responses-26d521c1/ 
Permana, Sony Hendra (2019). Wacana Maskapai Penerbangan Asing Masuk Dalam Rute Penerbangan Domestik Indonesia. Jurnal Ekonomi dan Kebijakan Publik, Volume XI Nomor 11, 2019.

Reynas Abdila (2021). BPS: Januari-Maret 2020, Penumpang Transportasi Udara Anjlok. $\quad$ https://www.tribunnews.com/bisnis/2020/05/04/bps-januari-maret-2020penumpang-transportasi-udara-anjlok.

Sukmana, Yoga (2019). BPS: Januari-April 2019, Jumlah Penumpang Pesawat Anjlok 20,5 Persen. https://money.kompas.com/read/2019/06/10/144700026/bps--januari-april-2019jumlah-penumpang-pesawat-anjlok-20-5-persen

Suryana, Sugiono, Sekaran, U., Lee, S., Stearns, T., \& Geoffrey, G. M. (2013). Metode penelitian kuantitatif, kualitatif, dan $R$ and D. International Journal of Management. 3(11), 1-14.

Tjiptono, Fandy., Gregorius Chandra. (2011). Service, Quality, \& Satisfaction, Edisi 3 Yogyakarta: Andi.

Zeithaml, V. A., Bitner, M. J., \& Gremler, D. D. (2010). Services marketing strategy. Wiley international encyclopedia

of marketing. https://doi.org/10.1002/9781444316568.wiem01055 